\title{
Economic Value Added (EVA) for Performance Evaluation of Public Organizations
}

\author{
Meena Subedi ${ }^{1} \cdot$ Ali Farazmand $^{1}$
}

Accepted: 17 September 2020 / Published online: 23 October 2020

(C) Springer Science+Business Media, LLC, part of Springer Nature 2020

\begin{abstract}
This study tests whether economic value added (EVA) as a performance evaluation metric incentivizes public administrators to increase the performance of public organizations. It utilizes data from Wind Info Database (WIND) and finds that the adoption of EVA as a performance evaluation metric incentivizes public administrators to increase the overall efficiency of the public organizations under study. The study suggests that public administrators make prudent investment and operating decisions after the adoption of EVA as their performance evaluation metric, thereby increasing the overall organizational performance. Using 2274 firm-year observations for the period from 2009 to 2010 in China, this paper uses first-difference change analysis methodology that takes care of firm-level unobservable heterogeneities and addresses endogeneity concerns, thereby producing robust results. The change analysis setting has been used in prior studies to find the effect of certain treatment (e.g., Lyons et al. 2001; Kerr et al. 2006; Pal and Pohit 2014). Lyons et al. (2001) argue that the change analysis focuses on studying differences before and after services (i.e., the presence and absence of treatment) that are received. In our research design, the treatment is adoption of EVA by the SASAC, which occurred in year 2010 .
\end{abstract}

Keywords Economic value added · Firm performance - Organizational performance, earnings before taxes $\cdot$ Return on equity $\cdot$ Public or state-owned enterprises (SOE, PE)

Meena Subedi

msubedi2014@fau.edu

Ali Farazmand

afarazma@fau.edu

1 Florida Atlantic University, 777 Glades Road, Boca Raton, FL 33431, USA 


\section{Introduction}

Economic Value Added (EVA) has been applauded to be the most recent and exciting innovation in the managerial performance evaluation measure. ${ }^{1}$ Prior research considers EVA as more potent than traditional measures of accounting profit in explaining market evaluation of the company (Chen and Dodd 1997; Young et al. 2000). The SASAC (State-Owned Assets Supervision and Administration Commission) ${ }^{2}$ had been using earnings before taxes and extraordinary items (EBT) and return on equity (ROE) in its performance score formula across all state-owned enterprises (SOEs) in China until 2009. However, beginning in 2010, the SASAC replaced ROE with economic value added (EVA). EVA equals net operating profit after tax less the cost of capital. The basic idea for EVA is that investors require a rate of return that compensates them for the use of their capital or the equivalent of their opportunity cost, and the level of risk undertaken.

SASAC finds that EBT and ROE as two financial measures for performance evaluation of SOEs are faulty. It has led to overspending on capital projects, with lower returns, because the loans were available very cheaply. Even then, the returns from the projects were sometimes lower than the interests on the loans taken from banks. This was the reason why SASAC replaced ROE with Economic Value Added (EVA) as the second measure for performance evaluation of SOE. They conjectured that post EVA period, the SOEs have been cautious in their capital expenditure. SOE managers will be more careful while selecting their investments as a lower value of EVA could reduce their overall rating from SASAC. Lower ratings could mean less reputation $^{3}$ and high threat of job turnover ${ }^{4}$ to these SOE managers. Thus, these managers will not accept the projects that have return lower than the bank loan interest.

This paper investigates whether the adoption of EVA by SASAC as a performance measure leads to the SOEs' improvement in EVA performance. It also investigates whether the effect of EVA adoption as a performance measure on the improvement of EVA performance becomes stronger for state-owned companies and manufacturing companies. The research is important in that it shows whether the EVA as a measure for performance evaluation is having its intended effects. The empirical evidence that supports this relationship would also incentivize other interested parties and including other countries adopting a similar performance evaluation metric. Similarly, the crosssectional analyses provide further evidence that only firms with certain characteristics have a stronger relationship will further help to tailor the evaluation metrics by firms' characteristics. Yes, the finding suggests that the SASAC replacement of ROE with economic value added (EVA) in performance evaluation does lead to an improvement in SOE's EVA. Further, this paper seeks to confirm whether the organizational change

\footnotetext{
${ }^{1}$ Economic Value Added (EVA) is calculated by subtracting the opportunity cost of the capital from profits generated (De Villiers 1997).

${ }^{2}$ SASAC stands for State-Owned Assets Supervision and Administration Commission, which was created in November 2002 to ensure that SOEs advance the interests of the Chinese government.

${ }^{3}$ SOE managers believe that obtaining such a rating is a great honor. In addition, the SASAC reinforces this honor by publishing annually a list of A-rated SOE managers.

${ }^{4}$ Since it has been mentioned that SOE managers who receive a lower rating could be asked to resign from their current position. Although job turnover due to low ratings rarely happens, just the idea that the one could be get fired would make the individual managers more risk-averse while selecting projects. More specifically, they will do very good job on finding projects that provide return greater than the cost of capital.
} 
in performance evaluation has achieved its intended purpose. However, this study cautions that such an intended effect is only present in firms with government ownership and firms in the non-manufacturing industry.

In addition, the Chinese economy is the second largest in the world, with a GDP of over \$12 trillion (Riley and Sherman 2018; Du et al. 2018). Similarly, the state-owned enterprise (SOE) system in China accounts for approximately $43 \%$ of business activity and $85 \%$ of state bank loans in China (Cary 2013; Du et al. 2018). Thus, the SOE system is of global economic significance. This research adds to this global significance matter in that the study seeks to investigate whether the adoption of a new performance evaluation metric has its intended effects. One must keep in mind the throughout the world, including the United States, Britain, Australia, France, Canada, and elsewhere, state or public enterprises (SOE or PE) have been instrumental in massive economic and social developments, and still do in many areas of the economy and society worldwide (see Farazmand 1997 for cases studies on this issues). In countries like Russia, Brazil, India, Iran, Australia state capitalism and public enterprises have played and still play a formidable role in the economy. The same was in the United Kingdom and the United States prior to the sweeping privatization craze of the 1980s.

Similarly, the paper contributes to the public administration and public management literature (Bourgon 2007; Farazmand 2002a, 2007, 2009, 2017, forthcoming). Incentivizing the managers of the state-owned enterprise to serve the broader interests of the general public is one of the critical areas to public administration. Swiss (2005) points out that result-oriented incentives in governmental management systems help produce expected positive outcomes. This study focuses on the adoption of EVA as a managerial performance evaluation metric to incentivize managers and to align the interests of managers and other stakeholders (i.e., the general public for state-owned enterprises). More specifically, this paper contributes to the organization theory and public administration in that it addresses organizational configuration and governance aspects of the public organizations (Farazmand 1989, 2002b) and the role public enterprise organizations have played in economic and social development across the world (Farazmand 2001, 1997, 1989). Farazmand (2002b) points out that public organizations have to deal with a more intrusive and politicized environment than private organizations and therefore conclude that private managers outperformed public administrators when it comes to achieving organizational goals, but may be underperforming if all social costs the government bears by supporting the private sector and offering an enabling environment for the private organizations, not to mention the major bail-out supports government provides to private sector organizations in times of economic, social, and health crises. ${ }^{5}$ Taking these social, economic, and health related costs into the equations of economic performance in comparisons, the public sector organizations may be considered outperforming the private sector in general while recognizing the microlevel analysis of private organizations' agility to cut costs and raise benefits/profits in

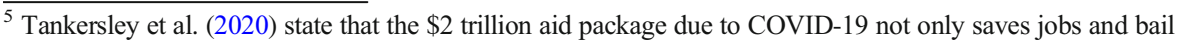
out companies, but it also reorders the relationship between government and private industry. Similarly, during the financial crisis of 2007-2008, the government provided unprecedented amounts of assistance worth $\$ 700$ billion in taxpayers' money to bail out for profit companies such as banks, automakers, and insurance companies (Collins 2015). The US government allocated $\$ 2$ billion to fund banks, railroads and other privately held companies during the Great Depression of 1930s (Olson 2017).
} 
contractual arrangements as well as large scale operations with economy of scale and accumulated expertise (Farazmand, forthcoming).

This study contributes to this issue in that it finds the adoption of EVA as a performance metric incentivizing public administrators to increase the overall efficiency of the firms.

To determine EVA, this study follows Du et al. (2018) and defines EVA as net operating profit after tax minus the cost of capital. The underlying concept is that investors require a rate of return that compensates them for the use of their capital or the equivalent of their opportunity cost, and the level of risk undertaken. Stewart (1991) is credited for the concept of EVA, and he calculated EVA based on an earlier construct known as residual income method developed by Edwards and Bell (1961). The major difference between economic value added (EVA) and residual income (RI) is on the determination of projected revenues. EVA includes more adjustments to the accounting measure of earnings. See "Research design section" for further details on how the SASAC computes EVA. This study matches the SASAC data with other financial information. The sample period covers two years: 2009 and 2010. 2010 is the year of the EVA adoption, and 2009 is the pre-adoption year. The final sample size is 3374 firm-year observations.

This paper provides both univariate and multi-variate evidence that the adoption of EVA has led to an improvement in the firms' EVA Performance. The main result is also economically significant in that the adoption of EVA as a measure for performance metric seems to improve the firm overall performance by 0.0046 , which represents $13.94 \%$ of overall EVA of the sample firms. Similarly, the cross-sectional analyses suggest that the positive effect of adoption is only prevalent in state-owned firms and non-manufacturing firms.

The rest of the paper is organized as follows. Section 2 discusses the prior literature and develops hypotheses. Section 3 explains the development of research design. Section 4 provides sample selection, and main empirical results, and Section 5 concludes.

\section{Literature Review and Hypothesis Development}

Economic value added (EVA) has been getting plenty of attention during the last few decades as a new form of performance measurement. The theory of EVA has traditionally suggested that all companies should strive to increase the shareholders' wealth. However, the companies used the traditional metrics such as return on assets (ROA), return on investment (ROI) and earnings before taxes (EBT) to align managerial interests to shareholders interests (Siniak and Lozanoska 2019). ${ }^{6}$ The corporate advisory firm, Stern Stewart \& Co., commercially made available EVA as an analytical tool in 1982. The advisory firm claimed that their new metric "Economic Value Added (EVA)" measure the true economic profitability and possess a strong positive

\footnotetext{
${ }^{6}$ Prior studies have also pointed the importance of qualitative characteristics such as social capital (Subedi and Farazmand 2019) and socially responsible behavior (Bhandari and Kohlbeck 2018) for the success of the organizations.
} 
correlation with the shareholders' value. Finegan (1989) was the first scholar to use the concept of EVA in research.

The concept of EVA received broader attention after the publication of an EVA related article in a Fortune magazine by Tully. In the early 1990s, when the concept of EVA as a metric for performance evaluation was evolving, Tully (1993) pointed out in a Fortune magazine article that firms that use EVA have a competitive advantage compared to firms that do not use EVA. Since the 1990s, an increasing number of companies responded to EVA as a new performance metric to reward managers. Brewer et al. (1999) point out that one has to discuss the other metrics of performance evaluation, such as return on investment (ROI), return on assets (ROA), and earnings before taxes (EBT) to assess the advantage of EVA accurately. Parvaei and Farhadi (2013) show that EVA is the best measure for evaluating the performance of firm and management, among other measures.

Similarly, Vijayakumar (2011) documents that out of traditional financial metrics including sales, and profit after tax have more robust relationship with EVA. Sirbu (2012) points out that EVA promises an effective way to manage shareholder value and that it aligns management's objectives with those of the shareholders, improves accountability, and enables better performance analysis. Therefore, it is not surprising that EVA, as a management tool, is in the spotlight.

Machuga et al. (2002) show that EVA is value relevant information to the analysts and that it contains information incremental to the traditional measure of earnings per share (EPS). An international study in the Indian context provides evidence that managerial ethics helps generate EVA (Mittal et al. 2008). More specifically, Mittal et al. (2008) study the corporate social responsibility (CSR) practices by the Indian companies and argue that CSR goals have to be integrated with stockholders' goal to increase EVA. Another international study in the Indian context documents that investors should use EVA along with traditional measures in firm valuation and in formulating investment strategy (Sharma and Kumar 2012). In line with the same argument, Bhandari \& Kohlbeck (2018) find that CSR practices by firms are value relevant information to analysts and have implications to the firms' performance. Analysts have been considered as the sophisticated investors who take wide range of value relevant information into consideration (Bhandari et al. 2018). Combining all the above arguments from various studies, EVA seems to carry other incremental information such as CSR and managerial ethics than compared to traditional measures of firm performance.

In analyzing farm businesses, Ibendahl and Fleming (2003) argue that EVA has advantages over other financial ratios because it fully accounts for the resources used on the farm, and it includes both realized and unrealized capital gains in the calculation. They point out that the four traditional financial (i.e., profitability) measures recommended by the Farm Financial Standards Task Force have limitations for examining wealth creation. Similarly, Bahri et al. (2011) show that EVA can be a useful tool for performance management in small and medium-sized enterprises (SMEs).

ROI, ROE, and EBT as financial metrics to assess managers' performance could be faulty because it has led to overspending on capital projects, with lower returns, because the loans were available very cheaply (Du et al. 2018). The main limitation of ROI, ROE, and EBT as performance evaluation metrics is that it can encourage managers, who are evaluated and rewarded based solely on this measure, to make 
investment divisions that are in their own best interests, while not being in the best interests of the company as a whole (Morse et al. 1996; Brewer et al. 1999). EVA overcomes this major limitation in that it brings the managerial and firm-level goals together. This article expands on this below in the context of EVA as a performance evaluation metric adopted by SASAC.

The SASAC had been using EBT and ROE in its performance score formula across all SOEs until 2009. SASAC finds that EBT and ROE as two financial measures for performance evaluation of SOEs are faulty. It has led to overspending on capital projects, with lower returns, because the loans were available very cheaply. ${ }^{7}$ More specifically, these state-owned enterprises were able to raise capital easily via the help of the government. Even then, the returns from the projects were sometimes lower than the interests on the loans taken from banks. This was the reason why SASAC decided to use Economic Value Added (EVA) as the second measure for performance evaluation. They conjectured that post EVA period, the SOEs have been cautious in their capital expenditure. SOE managers will be more careful while selecting their investments as a lower value of EVA could reduce their overall rating from SASAC. Lower ratings could mean less reputation and high threat of job turnover to these SOE managers. Thus, these managers do not accept the projects that have return lower than the bank loan interest.

This study identifies two mechanisms via which the adoption of EVA affects SOE's performance. First, the reputation associated with higher performance evaluation. It has been shown that SOE's managers regard an A rating by the State-Owned Assets Supervision and Administration Commission (SASAC) as a matter of prestige. SOE managers believe that obtaining such a rating is a great honor. In addition, the SASAC reinforces this honor by publishing annually a list of A-rated SOE managers. Thus, SOE managers will be cautious while selecting their investments as a lower value of EVA could reduce their overall rating from SASAC. More specifically, these managers will not accept the projects that have return lower than bank loan interest. Second, these managers value job security. Since it has been mentioned that SOE managers who receive a lower performance rating could be asked to resign from their current position. Although job turnover due to low ratings rarely happens, just the idea that one could be get fired would make the individual managers more risk-averse while selecting projects. More specifically, they will do a good job of finding projects that provide a return higher than the cost of capital.

Thus, this paper conjectures that the adoption of EVA by SASAC as a performance measure leads to the SOEs' improvement in EVA performance. The following hypothesis is stated in the alternative form:

H1: The adoption of EVA as a new measure of performance metric leads to the overall improvement of the firm performance.

The sample firms include the Chinese listed companies that are central government-owned companies, local government-owned companies, and private companies. This can be further classified into two categories as government-

\footnotetext{
${ }_{7}^{7}$ Researches on for-profit area also discuss about the influence of government and politics in profit companies (Hassan et al. 2019; Bhandari et al. 2020).
} 
owned (hereafter, public companies) and privately-owned companies. Since private companies had to compete for financing prior to EVA adoption and the financing were not cheaply available compared to the public companies, it seems logical to argue that the effect of EVA adoption in improving firms' performance should be more prevalent in public companies that compared to private companies. ${ }^{8}$ The idea here is that since state owned enterprises had access to cheap financing prior to EVA adoption, the effect of the adoption of EVA should be higher in state-owned enterprises. These firms borrowed cheaply and carelessly before EVA adoption, and hence, higher improvement should be seen after adoption in these firms. Therefore, this study predicts and tests whether the adoption of EVA as having a positive effect on firms' financial performance only in state-owned enterprises.

H2: The positive effect of EVA adoption on firm performance is higher for public companies than private companies.

Both Hypothesis 1 and Hypothesis 2 are presented in the form of conceptual predictive validity framework proposed by Kinney and Libby (2002) (Fig. 1).

\section{Research Design}

\section{EVA Measure}

This study follows Du et al. (2018) and adopted EVA measure from their study. EVA calculation is detailed below to provide for further specifics on how the SASAC computes EVA. EVA is scaled by the firm size following Pham et al. (2011). The idea is that EVA will be proportionate to the size of the firm and thus scaling EVA by total assets is recommended in Pham et al. (2011).

Explanation of Economic Value Added (EVA) Calculation

\begin{tabular}{ll}
\hline & EVA $=$ Net Operating Profit - Adjusted Capital $\times$ Cost of capital \\
Net Operating & Net Income $+0.75 \times($ Interest + R\&D Expense $-0.5 \times$ Non-Recurrent Income $)$ \\
Profit & \\
Adjusted Capital & $\begin{array}{c}\text { Owners' Equity }+ \text { Total Liabilities }- \text { Interest-Free Current Liability }- \text { Construction in } \\
\text { Progress } \\
\text { (in defined core businesses) }\end{array}$ \\
& $\begin{array}{l}5.5 \% \text { in principle. } \\
\text { Cost of capital }\end{array}$ \\
& construction. \\
& The cost of capital increases by $0.5 \%$ when manufacturing (non-manufacturing) firms have \\
a leverage ratio larger than $0.75(0.80)$.
\end{tabular}

Note: This EVA formula, including the cost of capital component, was in effect for the entire post-EVA period (2010-2012). This is adopted from Du et al. (2018)

\footnotetext{
${ }^{8}$ On a related concept, some studies have also recommended partnership between private and public organizations to bring the best of the both worlds (Subedi 2020).
} 


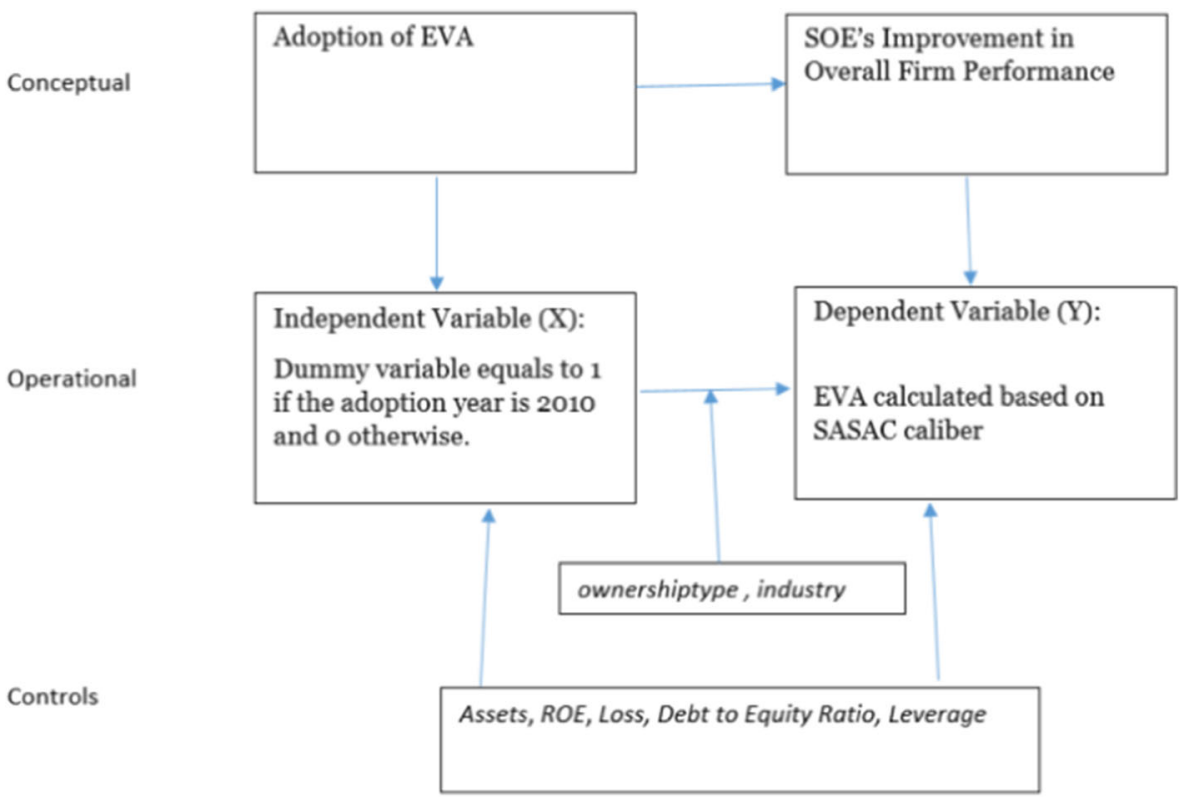

Fig. 1 Predictive Conceptual Framework

\section{Empirical Models}

To test $\mathrm{H} 1$, this paper estimates the following regression model:

$$
\begin{aligned}
\text { EVA_Scale } i, t= & \beta 0+\beta 1 \text { EVA_ADOPT_Dummy } i, t+\beta 2 \text { LNASSETS } i, t \\
& +\beta 3 \text { ROE } i, t+\beta 4 \text { LOSS_Dummy } i, t+\beta 5 \text { DERATIO } i, t \\
& +\beta 6 \text { LEVERAGE } i, t+\beta_{7} \text { INDUS_Dummy } \\
& +\beta 8 \text { OWNER_Dummy }+\varepsilon_{i, t}
\end{aligned}
$$

where EVA_Scale is main dependent variable of interest and is defined above in detail. The main independent variable of interest, EVA_ADOPT_DUMMY, equals to 1 if the adoption year is 2010 and 0 otherwise.

This study controls for firm size (LNASSETS) and profitability (ROE and LOSS_Dummy) as larger and profitable firms have greater resources to improve EVA. This study also controls for firms' leverage (DERATIO and LEVERAGE) because highly leveraged firms struggle to improve their EVA. To minimize the impact of invariant industry and ownership type characteristics, year and ownership type fixed effects are included. More specifically, INDUS_Dummy equals to 1 if the firm is in manufacturing industry, and 0 otherwise. Similarly, OWNER_Dummy equals to 1 if the firm's ownership type is governmental, and 0 otherwise (i.e., private).

Consistent with the first hypothesis, a positive coefficient is expected on $E V A \_A D O P T \_D U M M Y$, which would suggest that firm overall EVA performance improved after the adoption of EVA as a new performance evaluation metric. 
This study notes that industry control and ownership type controls are irrelevant in models with firm fixed effects. It argues that firm fixed effects (first stage difference) is more prudent regression method in this analysis because this research should show within firm variation in EVA from pre-adoption to post-adoption period. Thus, alternatively, the following regression model is proposed.

$$
\begin{aligned}
\text { EVA_Scale } i, t= & \beta 0+\beta 1 \text { EVA_ADOPT_Dummy } i, t+\beta 2 \text { LNASSETS } i, t \\
& +\beta 3 \text { ROE } i, t+\beta 4 \text { LOSS_Dummy } i, t+\beta 5 \text { DERATIO } i, t \\
& +\beta 6 \text { LEVERAGE } i, t+\text { Firm Fixed Effects }+\varepsilon_{i, t}
\end{aligned}
$$

All variables are defined above. In line with hypothesis 1 prediction, a positive coefficient on EVA_ADOPT_DUMMY is expected, which would suggest that firm overall EVA performance improved after the adoption of EVA as a new performance evaluation metric. This evidence will be more robust than compared to evidence obtained from Eq. (1) in that Eq. (2) considers and controls for all time invariant firm characteristics (such as firm headquartered area, firm level culture, and family firm vs. non-family firm) that could be driving the results. The change analysis setting has been used in prior studies to find the effect of certain treatment (Lyons et al. 2001; Kerr et al. 2006; Pal and Pohit 2014). Lyons et al. (2001) argue that the change analysis focuses on studying differences before and after services (i.e., the presence and absence of treatment) are received. In our research design, the treatment is adoption of EVA by the SASAC, which occurred in year 2010.

\section{Sample Selection and Empirical Results}

\section{Sample and Descriptive Statistics}

The final sample size is 3374 firm year observations. The sample firms include the Chinese listed companies that are coded as central government owned companies, local government owned companies, and private companies. The sample period covers two years: 2009 and 2010. Year 2010 is the year of the EVA adoption and 2009 is the preadoption year. This provides a nice setting to test within firm variation as these firms progress from year 2009 to year 2010 as it allows us to see whether the EVA adoption has its intended effect. All these variables including the control variables discussed above are defined in Table 1.

Table 2 presents the descriptive statistics pertaining to the variables used in the empirical analyses. ${ }^{9}$ The mean of EVA is $-\$ 25,896$ whereas the median is $\$ 4747$. This suggests that larger number of firms in the sample has positive EVA whereas there are a few firms with large negative EVA values which make the mean EVA negative. Similarly, the mean value of EVA_ADOPT_DUMMY equals to 0.546 which suggests that half of the sample firms are in the post adoption period. The mean value of ROE is 0.083 which suggests that on average sample firms are profitable in terms of return on

\footnotetext{
${ }^{9}$ All continuous variables are winsorized at the 1 and 99 th percent level.
} 
Table 1 Variable Definitions

\begin{tabular}{ll}
\hline EVA & $=$ Economic Value Added calculated based on SASAC formula; \\
\hline EVA_Scale & $=$ EVA scaled by total assets; \\
EVA_ADOPT_Dummy & $=$ Dummy variable equals to 1 if the adoption year is 2010 and 0 otherwise; \\
ASSETS & the total assets of company; \\
LNASSETS & the natural logarithm of total assets; \\
ROE & Return on Equity measures financial performance of a company by measuring \\
& $\quad$ net income divided by Owner's(shareholder's) equity; \\
LOSS_Dummy & 1 if net income is negative, and 0 otherwise; \\
DERATIO & Debt-To-Equity Ratio - refers to a type of liquidity ratio that shows total \\
& $\quad$ liabilities/total equity - denotes percentage of company financing sourced \\
fEVERAGE creditors (bank loans) vs. investor financing (shareholders); \\
INDUS_Dummy & the use of debt/credit to increase potential return of an investment; \\
OWNER_Dummy & $=1$ if the firm is in manufacturing industry, and 0 otherwise; \\
& $=1$ if the firm's ownership type is governmental, and 0 otherwise (i.e., private);
\end{tabular}

Notes: Table 1 defines variables used in this study

equity. Similarly, the mean value of LOSS_DUMMY is 0.071 . Thus $7.1 \%$ of sample firms have net loss. The mean value of DERATIO is 1.525 which suggests that on average the sample firms have higher total debt than compared to total equity. Similarly, the mean value of leverage is 0.474 which suggests that on average the sample firms' total liabilities represents $47.4 \%$ of the total assets. In addition, the descriptive statistics suggest that $23 \%$ of sample firms are in the manufacturing industry and $55.8 \%$ of sample firms are owned by the government.

The Pearson correlation coefficients on variables yield some interesting insights, and are generally consistent with prior studies (e.g., Due et al. 2019). Table 3 presents Pearson correlation matrix pertaining to the variables used in this study. Correlation coefficients that are significant at $1 \%$ level have one star. Coefficients that are significant at 5\% level are in bold format and those that are significant at $10 \%$ level are italicized. The correlation coefficient between EVA_ADOPT_Dummy (i.e., independent variable) and EVA_Scale (i.e., dependent variable) is 0.0606 which is positive and significant at $1 \%$ level. This provides univariate support to Hypothesis 1 that there is a positive relationship between EVA adoption and improvement in firms' EVA performance. ROE and EVA_SCALE are positively correlated at $1 \%$ significance level whereas the correlation between LOSS_DUMMY and EVA_SCALE are negative. Both DERATIO and LEVERAGE are negatively correlated with EVA_SCALE.

\section{Empirical Results}

Table 4 reports the regression results for the impact of EVA adoption on the firm's expost improvement in the financial performance. Table 4 Column (1) presents regular OLS regression where any significant relationship between EVA_ADOPT_Dummy and $E V A \_$Scale was not found. However, firm fixed effects (first stage difference) is more prudent regression method because it considers within firm variation in EVA from preadoption to post-adoption period (Wooldridge 2010). Table 4 Column (2) presents 


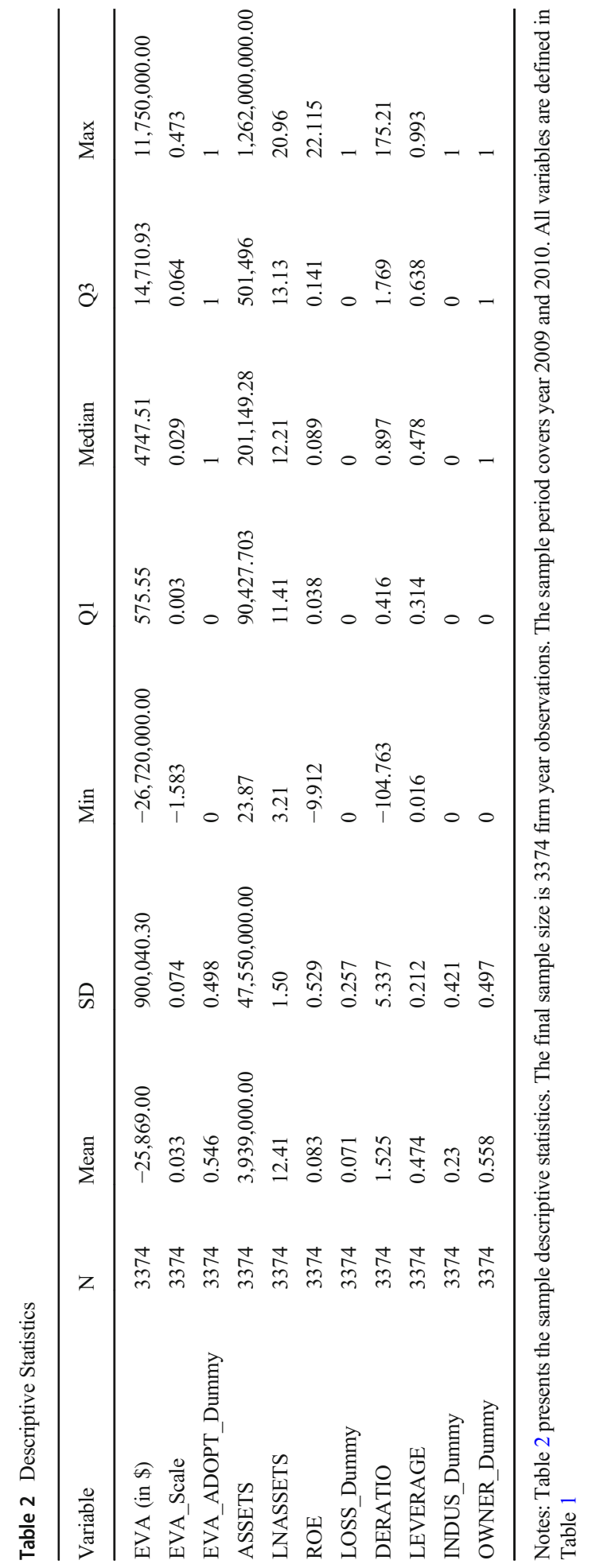




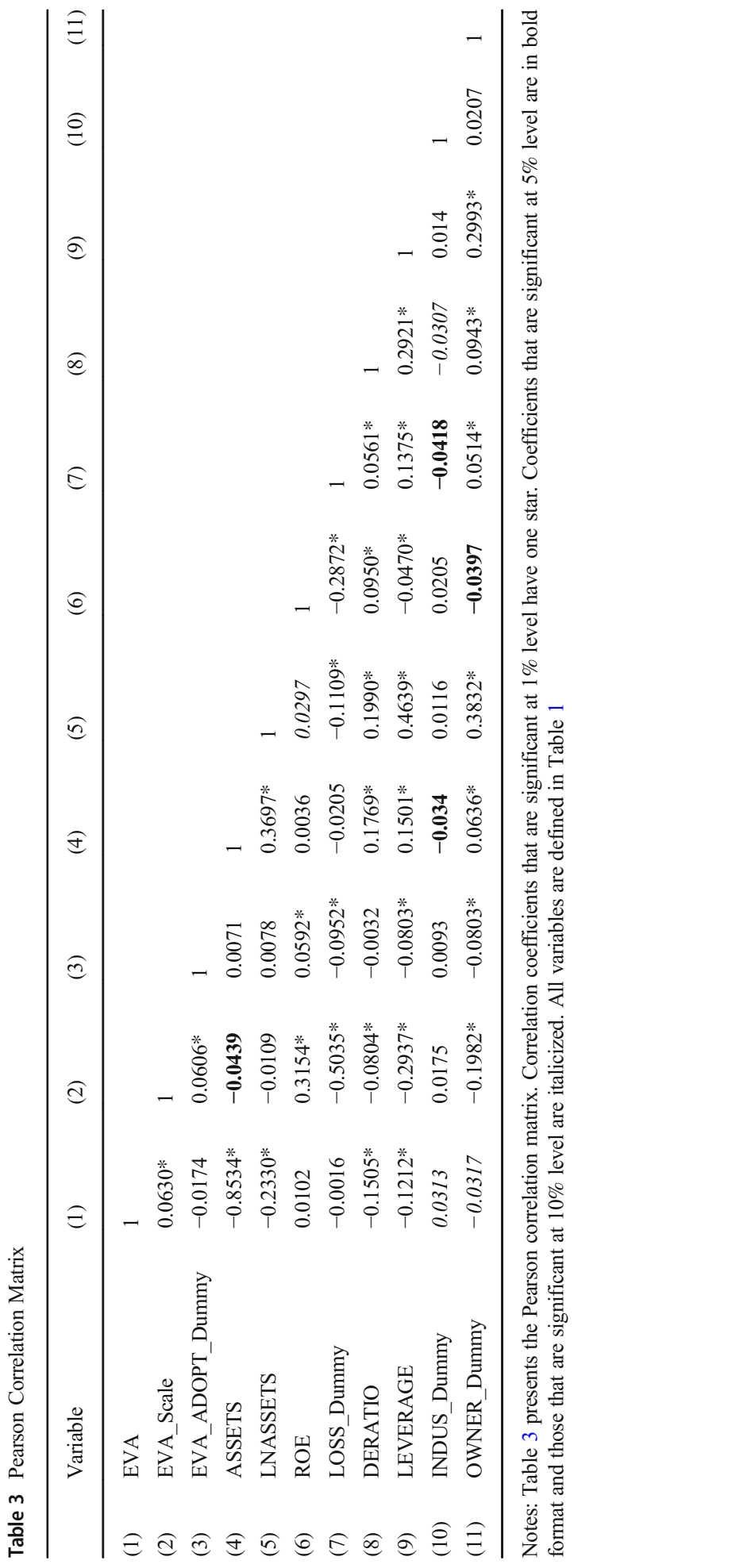


results using firm fixed effects regression. The coefficient on EVA_ADOPT_Dummy is 0.0046 which is positive and significant at $1 \%$ level. This suggests that firms on average improved their EVA performance as they transitioned from year 2009 to 2010. The rationale for firm fixed effects is also supported by higher within firm variation than between firm variation in the regression results. The main result is also economically significant in that the adoption of EVA as a measure for performance metric seems to improve the firm overall performance by 0.0046 which represent $13.94 \%$ percentage of overall EVA of the sample firms. ${ }^{10}$

Similarly, this study tests Hypothesis 2 in Table 5. More specifically, in Table 5, sample is partitioned into government ownership and private ownership firms. This study expects that since state-owned firms borrowed cheaply and carelessly before EVA adoption, the effect of EVA adoption on EVA would be higher if ownership type is state owned (OWNER_Dummy =1) than compared to private companies $\left(O W N E R \_\right.$Dummy $\left.=0\right)$. The coefficient on EVA_ADOPT_Dummy is positive and significant only in Column (1) which suggests that the positive effect of adoption is only prevalent in state owned firms not in private firms. In terms of economic significance, this result is economically significant in that the adoption of EVA as a measure of performance evaluation seems to improve the state-owned companies' overall EVA performance by 0.0101 which represents $30.61 \%$ percentage of overall EVA of the sample firms. ${ }^{11}$

\section{Additional Analysis}

In Table 6 sample is partitioned into two groups: firms in the manufacturing industry and firms in the non-manufacturing industry. This study finds that the positive effect of $E V A \_A D O P T \_D u m m y$ is only present in non-manufacturing firms. This finding suggests that non-manufacturing companies were more prone to making investments without properly analyzing the market for their products, and they were more reckless in borrowing and investment during the pre-adoption period. The finding opens the door for more future research in that future research can examine other cross-sectional variations and underlying reasons across different industry classifications such as technological vs. non-technological firms and Fama French twelve and forty-eight industry classification.

\section{Conclusion}

A growing literature documents that managerial performance evaluation metrics affect various corporate decisions (e.g., Keating 1997; Den Hartog and Verburg 2004; Cichello et al. 2009). Several prior studies recommended EVA as a metric for managerial performance evaluation (Sirbu 2012; Siniak and Lozanoska 2019). This study investigates whether EVA as a measure for managerial performance evaluation help actually improve organization's performance. Findings, derived from the Chinese government's performance evaluations of State-Owned Enterprises, suggest that

\footnotetext{
${ }^{10} 0.0046 / 0.033=0.1394$

${ }^{11} 0.0101 / 0.033=0.3061$
} 
Table 4 The effect of EVA Adoption on improvement of EVA (Dependent Variable=EVA_Scale)

(1)

\begin{tabular}{|c|c|c|}
\hline \multirow[t]{2}{*}{ Intercept } & $0.0267 * * *$ & $0.4221 * * *$ \\
\hline & $(2.8732)$ & $(7.3525)$ \\
\hline \multirow[t]{2}{*}{ EVA_ADOPT_Dummy } & -0.0029 & $0.0046^{* * *}$ \\
\hline & $(-1.3809)$ & $(2.8889)$ \\
\hline \multirow[t]{2}{*}{ LNASSETS } & $0.0052 * * *$ & $-0.0348 * * *$ \\
\hline & $(6.2243)$ & $(-7.5528)$ \\
\hline \multirow[t]{2}{*}{ ROE } & $0.0256 * * *$ & $0.0525 * * *$ \\
\hline & $(12.5532)$ & $(14.9148)$ \\
\hline \multirow[t]{2}{*}{ LOSS_Dummy } & $-0.1154 * * *$ & $-0.0734 * * *$ \\
\hline & $(-26.8200)$ & $(-18.5214)$ \\
\hline \multirow[t]{2}{*}{ DERATIO } & -0.0002 & $-0.0004 *$ \\
\hline & $(-0.9915)$ & $(-1.6953)$ \\
\hline \multirow[t]{2}{*}{ LEVERAGE } & $-0.0815^{* * *}$ & $0.0870 * * *$ \\
\hline & $(-14.0808)$ & $(4.7000)$ \\
\hline \multirow[t]{2}{*}{ INDUS_Dummy } & 0.0003 & Not Applicable \\
\hline & $(0.1255)$ & \\
\hline \multirow[t]{2}{*}{ OWNER_Dummy } & $-0.0209 * * *$ & Not Applicable \\
\hline & $(-9.2222)$ & \\
\hline Firm Fixed Effects & No & Yes \\
\hline Adj. $\mathrm{R}^{2}$ & $35.35 \%$ & NA \\
\hline $\mathrm{R}^{2}$ within & & $40.01 \%$ \\
\hline $\mathrm{R}^{2}$ between & & $2.82 \%$ \\
\hline $\mathrm{N}$ & 3374 & 3374 \\
\hline
\end{tabular}

Notes: Table 4 presents the results on the regression analysis testing the relationship between the adoption of EVA in performance measure and the improvement in EVA. The OLS regression model in Table 4 Column (1) does not include firm fixed effects. In Table 4 Column (1), any significant relationship between EVA_ADOPT_Dummy and EVA_Scale was not found. However, the firm fixed effects (first-difference change analysis) is more prudent regression method in the analysis because it allows us to see within firm variation in EVA from pre-adoption to post-adoption period. The OLS regression model in Table 4 Column (2) includes firm fixed effects. Reported significance is based on robust standard errors of two-tailed tests, adjusted for heteroscedasticity. t-statistics are presented in parentheses under the coefficient estimates

$* * *, * *$, and $*$ represent significance levels at 1,5 and $10 \%$ levels respectively. All variables are defined in Table 1

managers make more prudent investment and operating decisions after the adoption of EVA as their performance evaluation metric. In addition, this study provides evidence that the positive effect of EVA adoption on firm performance is only prevalent in a state-owned enterprise. This finding suggests that state-owned enterprises that had borrowed cheaply and carelessly, made the poor investment choices and operating decision before EVA adoption (i.e., prior to the year 2010), after the adoption of EVA, were more prudent on their investments and operating decisions, thereby improving the overall enterprise performance. 
Table 5 Cross-sectional analysis across government ownership vs. private ownership firms (Dependent Variable $=$ EVA_Scale)

\begin{tabular}{|c|c|c|}
\hline & $\begin{array}{l}\text { Non private ownership Sample, } \\
\text { OWNER_Dummy }=1\end{array}$ & $\begin{array}{l}\text { Private ownership sample, } \\
\text { OWNER_Dummy }=0\end{array}$ \\
\hline \multirow[t]{2}{*}{ Intercept } & $0.5666^{* * *}$ & $0.2934 * * *$ \\
\hline & $(5.4744)$ & $(4.6150)$ \\
\hline \multirow[t]{2}{*}{ EVA_ADOPT_Dummy } & $0.0101 * * *$ & -0.0022 \\
\hline & $(4.6724)$ & $(-0.9077)$ \\
\hline \multirow[t]{2}{*}{ LNASSETS } & $-0.0431 * * *$ & $-0.0256 * * *$ \\
\hline & $(-5.3452)$ & $(-4.7405)$ \\
\hline \multirow[t]{2}{*}{ ROE } & $0.0512 * * *$ & $0.0716^{* * *}$ \\
\hline & (11.6389) & (10.8366) \\
\hline \multirow[t]{2}{*}{ LOSS_Dummy } & $-0.0752 * * *$ & $-0.0693 * * *$ \\
\hline & $(-14.8616)$ & $(-11.2521)$ \\
\hline \multirow[t]{2}{*}{ DERATIO } & 0.0004 & $-0.0024 * * *$ \\
\hline & $(1.4672)$ & $(-5.8450)$ \\
\hline \multirow[t]{2}{*}{ LEVERAGE } & 0.0125 & $0.1412 * * *$ \\
\hline & $(0.4247)$ & $(6.2005)$ \\
\hline INDUS_Dummy & Not Applicable & Not Applicable \\
\hline OWNER_Dummy & Not Applicable & Not Applicable \\
\hline Firm Fixed Effects & Yes & Yes \\
\hline $\mathrm{R}^{2}$ within & $41.27 \%$ & $43.90 \%$ \\
\hline $\mathrm{R}^{2}$ between & $4.91 \%$ & $0.30 \%$ \\
\hline $\mathrm{N}$ & 1882 & 1492 \\
\hline
\end{tabular}

Notes: In Table 5, the sample is partitioned into government ownership (Column1, OWNER_Dummy =1) and private ownership (Column 2, OWNER_Dummy=0) firms. The OLS regression models include firm fixed effects and reported significance is based on robust standard errors of two-tailed tests, adjusted for heteroscedasticity. $\mathrm{t}$-statistics are presented in parentheses under the coefficient estimates

$* * *, * *$, and * represent significance levels at 1,5 and $10 \%$ levels respectively. All variables are defined in Table 1

This study adds to the organization theory and behavior in that the research addresses organizational configuration and governance aspects of the public organizations and their performances (Farazmand 1989, 1997, 2002b). Organizational performance is a key indicator of organizational effectiveness. Similarly, incentivizing the managers of the state-owned enterprise to serve the broader interests of the public is one of the critical areas to public administration and public management. Thus, this research has direct implications to public administration research by providing empirical evidence that the adoption of EVA as a performance metric incentivizes public administrators to increase the overall efficiency of their enterprises. Additionally, accounting approximately $43 \%$ of business activities and about $85 \%$ of state bank loans in China, the role of public enterprises (i.e., SOE), the study on SOEs in China is of global interest and has meaningful economic significance. Finally, this study confirms the instrumental role of public enterprises in economies and societies, a finding that might 
Table 6 Cross-sectional analysis across manufacturing vs. non-manufacturing firms (Dependent Variable = EVA_Scale)

(1)

Manufacturing Sample, INDUS Dummy $=1$

Intercept

$0.2217^{*}$

(1.7434)

EVA ADOPT Dummy 0.0018

(0.4980)

LNASSETS

$-0.0184 *$

$(-1.7910)$

ROE

$$
0.0135^{* *}
$$

LOSS_Dummy

$$
-0.0985^{* * * *}
$$$$
(-10.1621)
$$

DERATIO

$$
-0.0004
$$$$
(-0.7795)
$$

LEVERAGE

$0.0943^{* * * *}$

(2.7118)

INDUS_Dummy

Not Applicable

OWNER_Dummy

Not Applicable

Firm Fixed Effects

$\mathrm{R}^{2}$ within

Yes

$32.11 \%$

$\mathrm{R}^{2}$ between

$5.60 \%$

777
(2)

Non Manufacturing Sample, INDUS_Dummy $=0$

$0.4312 * * *$

(7.0355)

$0.0039 * *$

(2.2558)

$-0.0358^{* * * *}$

$(-7.2851)$

0.0857 ***

(19.1855)

-0.0619 ***

$(-14.7948)$

0.0002

(1.0503)

$0.0843 * * *$

(4.0599)

Not Applicable

Not Applicable

Yes

$47.90 \%$

$4.58 \%$

2597

Notes: In Table 6, the sample is partitioned into two groups: firms in manufacturing industry (Column1, INDUS_Dummy $=1$ ) and firms in non-manufacturing industry (Column 2, INDUS_Dummy $=0$ ). The OLS regression models include firm fixed effects and reported significance is based on robust standard errors of two-tailed tests, adjusted for heteroscedasticity. t-statistics are presented in parentheses under the coefficient estimates

$* * *, * *$, and * represent significance levels at 1,5 and $10 \%$ levels respectively. All variables are defined in Table 1

need to be considered in other countries as a major macro economic policy and public administration strategy for economic development. It does not negate the role of private sector in promoting market organizations in economy; in fact, the two sectors are equally important to enhancing organizational performance and economic and social developments. This study also further validates the fundamental question some scholars raised earlier $(1997,2001)$ via strategic case studies regarding governments' policy of "sweeping privatization or reforming public enterprises" across the (see, for example, Farazmand 1997, 2001).

Acknowledgements We thank Dr. Fei Du and Partha Mohapatra for many helpful comments and suggestions. 


\section{References}

Bahri, M., St-Pierre, J., \& Sakka, O. (2011). Economic value added: A useful tool for SME performance management. International Journal of Productivity and Performance Management, 60(6), 603-621.

Bhandari, A., Golden, J., \& Thevenot, M. (2020). CEO political ideologies and auditor-client contracting. Journal of Accounting and Public Policy, 106755.

Bhandari, A., \& Kohlbeck, M. (2018). Impact of corporate social responsibility activities on analysts. Advances in Quantitative Analysis of Finance and Accounting, 16, 73-116.

Bhandari, A., Mammadov, B., \& Thevenot, M. (2018). The impact of executive inside debt on sell-side financial analyst forecast characteristics. Review of Quantitative Finance and Accounting, 51(2), 283315 .

Bourgon, J. (2007). Responsive, responsible and respected government: Towards a new public administration theory. International Review of Administrative Sciences, 73(1), 7-26.

Brewer, P. C., Chandra, G., \& Hock, C. A. (1999). Economic value added (EVA): Its uses and limitations. SAM Advanced Management Journal, 64(2), 4.

Cary, E. (2013). Reforming China's state-owned enterprises. Diplomat (June 19).

Chen, S., \& Dodd, J. L. (1997). Economic value added (EVA): An empirical examination of a new corporate performance measure. Journal of Managerial Issues, 318-333.

Cichello, M. S., Fee, C. E., Hadlock, C. J., \& Sonti, R. (2009). Promotions, turnover, and performance evaluation: Evidence from the careers of division managers. The Accounting Review, 84(4), 1119-1143.

Collins, M. (2015). The big Bank bailout. Forbes.Com

De Villiers, J. (1997). The distortions in economic value added (EVA) caused by inflation. Journal of Economics and Business, 49(3), 285-300.

Den Hartog, D. N., \& Verburg, R. M. (2004). High performance work systems, organisational culture and firm effectiveness. Human Resource Management Journal, 14(1), 55-78.

Du, F., Erkens, D. H., Young, S. M., \& Tang, G. (2018). How adopting new performance measures affects subjective performance evaluations: Evidence from EVA adoption by Chinese state-owned enterprises. The Accounting Review, 93(1), 161-185.

Farazmand, A. (forthcoming). Public Administration in a Globalized World. Routledge/Taylor \& Francis

Farazmand, A. (2007). Global administrative reform and transformation of governance and public administration. In Ali Farazmand and Jack Pinkowski, eds., Handbook of Globalization, Governance, and Public Administration (Chapter 18/pp. 351-374). New York, Boca Raton: Taylor \& Francis.

Farazmand, A. (2017). Governance reforms: The good, the bad, and the ugly; and the sound: Examining the past and exploring the future of public organizations. Public Organization Review, 17(4), 595-617.

Farazmand, A. (2009). Building administrative capacity for the age of rapid globalization: A modest prescription for the twenty-first century. Public Administration Review, 69(6), 1007-1020.

Farazmand, A. (Ed.). (2002a). Administrative reform in developing nations. Greenwood Publishing Group.

Farazmand, A. (Ed.). (2002b). Modern organizations: Theory and practice. Greenwood Publishing Group.

Farazmand, A. (Ed.). (2001). Privatization or reform: Implications for public management. Westport, CT: Greenwood Press.

Farazmand, A. (Ed.). (1997). Public enterprise management: International case studies. Westport: Greenwood Press.

Farazmand, A. (1989). The state, bureaucracy, and revolution in modern Iran: Agrarian reforms and regime politics. Praeger Publishers.

Finegan, P. T. (1989). Financial incentives resolve the shareholder-value puzzle. Corporate Cashflow, 9, 2732.

Hassan, T. A., Hollander, S., van Lent, L., \& Tahoun, A. (2019). Firm-level political risk: Measurement and effects. The Quarterly Journal of Economics, 134(4), 2135-2202.

Ibendahl, G. A., \& Fleming, R. A. (2003). Using economic value added (EVA) to examine farm businesses (no. 1363-2016-107920).

Keating, A. S. (1997). Determinants of divisional performance evaluation practices. Journal of Accounting and Economics, 24(3), 243-273.

Kerr, T., Stoltz, J. A., Tyndall, M., Li, K., Zhang, R., Montaner, J., \& Wood, E. (2006). Impact of a medically supervised safer injection facility on community drug use patterns: A before and after study. $B M J$, 332(7535), 220-222.

Kinney Jr., W. R., \& Libby, R. (2002). Discussion of the relation between auditors' fees for nonaudit services and earnings management. The Accounting Review, 77(s-1), 107-114. 
Lyons, J. S., Terry, P., Martinovich, Z., Peterson, J., \& Bouska, B. (2001). Outcome trajectories for adolescents in residential treatment: A statewide evaluation. Journal of Child and Family Studies, 10(3), 333-345.

Machuga, S. M., Pfeiffer, R. J., \& Verma, K. (2002). Economic value added, future accounting earnings, and financial analysts' earnings per share forecasts. Review of Quantitative Finance and Accounting, 18(1), 59-73.

Mittal, R. K., Sinha, N., \& Singh, A. (2008). An analysis of linkage between economic value added and corporate social responsibility. Management Decision, 46(9), 1437-1443.

Morse, W., Davis, J., \& Hartgraves, A. (1996). Management accounting: A strategic approach. Cincinnati: Southwestern Publishing.

Olson, J. S. (2017). Saving capitalism: The reconstruction finance corporation and the new Deal, 1933-1940. Princeton University Press.

Pal, B. D., \& Pohit, S. (2014). Environmentally extended social accounting matrix for climate change policy analysis for India. Journal of Regional Development and Planning, 3(1), 61-76.

Parvaei, A., \& Farhadi, S. (2013). The ability of explaining and predicting of economic value added (EVA) versus net income (NI), residual income (RI) \& free cash flow (FCF) in Tehran stock exchange (TSE). International Journal of Economics and Finance, 5(2), 67-77.

Pham, P. K., Suchard, J. A., \& Zein, J. (2011). Corporate governance and alternative performance measures: Evidence from Australian firms. Australian Journal of Management, 36(3), 371-386.

Riley and Sherman (2018) World's largest economies. CNN Money (January 18).

Sharma, A. K., \& Kumar, S. (2012). EVA versus convenational performance measures-empirical evidence from India. ASBBS Proceedings, 19(1), 804.

Siniak, N., \& Lozanoska, D. K. (2019). A review of the application of the concept of economic and smart sustainable value added (SSVA) in industries performance evaluations. BRAIN. Broad Research in Artificial Intelligence and Neuroscience, 10(1), 129-136.

Sirbu, A. (2012). Economic value added (EVA) approach in Russia. Concepts. Approaches. Instruments. Revista de Management Comparat Internațional, 13(2), 305-312.

Stewart, G. B. (1991). The quest for value: a guide for senior managers. New York: HarperBusiness

Subedi, M. (2020). Public-private partnership and bureaucracy. In A. Farazmand (Ed.), Global encyclopedia of public administration, public policy, and governance. Cham: Springer. https://doi.org/10.1007/978-3319-31816-5 3823-2.

Subedi, M., \& Farazmand, A. (2019). Membership Organization's social capital and the impact on nonprofit sector management. International Journal of Public Administration, 42(10), 880-892.

Swiss, J. E. (2005). A framework for assessing incentives in results-based management. Public Administration Review, 65(5), 592-602.

Tankersley, J., Rappeport, A., Gelles, D., Eavis, P., \& Yaffe-bellany, D. (2020). The coronavirus economy: When Washington takes over business. NewYorkTimes.Com.

Tully, S. (1993). The real key to creating wealth. Fortune, 128(6), 38-50.

Vijayakumar, A. (2011). Economic value added (EVA) and shareholders wealth creation: A factor analytic approach. Research Journal of Finance and Accounting, 2(12), 22-37.

Wooldridge, J. M. (2010). Econometric analysis of cross section and panel data. MIT press.

Young, S. D., O'byrne, S. F., Young, D. S., Young, S., \& O'Byrne Stephen. (2000). EVA and value-based management. McGraw-Hill Professional Publishing.

Publisher's Note Springer Nature remains neutral with regard to jurisdictional claims in published maps and institutional affiliations.

Meena Subedi is a doctoral candidate in the School of Public Administration at Florida Atlantic University. She has presented at multiple conferences including the American Society for Public Administration and The Southeastern Conference for Public Administration. Meena's research interests include Nonprofit Management, Public Administration, and Non-profit financial reporting quality.

Ali Farazmand is a Professor in the School of Public Administration at Florida Atlantic University, where he has been teaching Ph.D. and MPA courses since 1995. He has a Ph.D. and MPA in Public Administration, and an MS in Educational Administration, all three from Syracuse University. His areas of research include Organization/Administrative Theory, Comparative/International PA, Crisis and Emergency Management, Administrative and Governance Reform, and Organizational Change \& Leadership. He is the author and editor of over 24 books and 140 journal articles, book chapters, and other publications. 